$11^{\text {th }}$ ICEEPSY 2020

The International Conference on Education and Educational Psychology

\title{
LESSON STUDY - MODERNIZATION OF UNDERGRADUATE TRAINING OF FUTURE PRIMARY SCHOOL TEACHERS
}

\author{
Dominika Provázková Stolinská (a)* \\ *Corresponding author \\ (a) Department of primary and pre-primary education, Faculty of education, Palacký University Olomouc, Žižkovo \\ nám 5, Olomouc, 771 40, Czech Republic, dominika.stolinska@gmail.com
}

\begin{abstract}
The new approach adopted by the Faculty of Education, Palacký University Olomouc is institutional accreditation of study programmes. These new strategies entail the modernization of undergraduate training of future teachers. The purpose of the paper is to introduce the Lesson Study method as an inspiration for the modernization of undergraduate training of future teachers. In the Czech Republic, this method has so far not been used extensively. However, we believe that its application may increase the effectiveness of undergraduate training. For a long time, university education has primarily focused on teaching theoretical knowledge without practical applications. The implementation of the "Lesson Study" method in undergraduate training may increase the effectiveness of the preparation for practice by involving several actors - supervisor (expert from university), teacher trainer (expert from elementary school), and a group of students. The aim of the paper is to outline the development and current trends in the practical aspects of undergraduate training of future primary school teachers.
\end{abstract}

2672-8141 (C) 2020 Published by European Publisher.

Keywords: Lesson study, practice, primary school, research. 


\section{Introduction}

The current concept of education in the Czech Republic is based on the national strategic and curricular documents inspired by European educational visions. The objectives of education are defined in the Strategy for Education Policy of the Czech Republic until 2020 (currently, a subsequent document is under preparation: Strategy for Education Policy until 2030), which in addition to career preparation declare the principles of personality development in order to improve the quality of human life, maintain and develop culture as a system of shared values, and develop active citizenship as a precondition for a society of solidarity, sustainable development, and democracy. The aspects of education that support these values are included in a comprehensive educational offer as defined in the Framework educational programme for elementary education (MŠMT, 2013), including all educational areas, cross-curricular subjects, and key competences.

\section{Problem Statement}

Until 1990s, the key elements of education policy, such as the educational content, school system, teaching organization, etc. had reflected the educational needs of the previous century. The aim of the curricular reform after 1989 was to improve the quality of education and take into consideration the requirements of the European Union. As a result, the concept of the child and the child's educational needs has gradually transformed. Before the school reform, children had been assessed according to standards instead of their potentialities, the development of which has now become a separate educational objective. One of the main objectives of education is the socialization of the child, which also involves the cultivation of the child's attitudes, values, and a holistic perspective of the world. The strategic curricular documents such as the White Paper (today replaced by the Strategy for Education Policy of the Czech Republic until 2020) or FEP define the potential educational procedures to achieve these objectives, including for example variable teaching methods and activity-based learning. The view of the learning content has also changed. Previously, school subjects were designed as "reductions" of scientific disciplines, which supported an encyclopaedic type of education. Today, the learning content is a means of developing students' key competences (learning, problem solving, communicative, social and personal, civil and work-related). The former predominant passivity of students has been replaced by active participation in learning. Today, the learning content should not be presented as the final product of the teacher's knowledge (Kasíková, 1994).

The curricular reform emphasised the necessity of the teacher's direct participation in the process of the child's socialization by means of the so-called social learning. This takes place through group and social forms of education with an emphasis on cooperation and through social integration of all students with an emphasis on the acceptance of one's individuality but also the individuality of others. The objectives of social learning also include the acquisition of the ability to solve problems in a group and to mediate and receive information.

Currently in the Czech Republic, the content of the curricular document Framework educational programme for elementary education (MŠMT, 2013) is under review.

Over the past thirty years, the system of Czech education has undergone a radical transformation. In this context it is important to implement the new aspects in undergraduate training of future primary 
school teachers. However, this is not enough. It is essential to create an educational system that is flexible and vibrant - only in this way it is possible to respond to the fast changing conditions.

\section{Research Questions}

What are the developments in undergraduate training of future primary school teachers in the

\section{Czech Republic?}

In 2004, the Czech Republic joined the European Union. This introduced the European idea in the transformation of the Czech society. Since then, Europe has not just inspired us but we have entered the structures built by Western Europe since the end of World War II (Walterová, 1997, 1998).

In the same year, the Faculty of Education in Olomouc joined the structural transformation of higher education on the basis of the Bologna Declaration, although the introduction of the concept of structured study was assessed as a "nationwide experiment" (according to the Concept of undergraduate preparation of elementary and secondary school teachers, 2004). However, thanks to the significant efforts of experts on undergraduate training of primary school teachers, the process of restructuring of the field of study was successfully avoided (In 2003, Masaryk University in Brno applied for accreditation of two-level undergraduate training of primary school teachers. This required the application of the so-called consecutive model of study, which is not suitable for the field of study. Experts argued "against" on the basis of both foreign and Czech historical trends already at the time, and eventually the arguments proved legitimate.). Their efforts were also supported by the Czech Accreditation Commission, who recommended an official exemption. As a result, Teacher training for primary schools remained unstructured (70th Anniversary of the Faculty of Education, Palacký University Olomouc, 2016).

Nevertheless, ways were sought to implement the ideas of the Bologna Declaration (the European reform of higher education) also in this field of study. One of the ways of achieving this was the modular structure of the study. In the first decade of the 21 st century, more than $80 \%$ of universities introduced the modular structure of study programmes, the purpose of which was to replace the traditional (linear) system. The modular system allows better passability through the study at both national and international levels. For students, this is motivating and especially flexible as they can change between fields of study (in case of an incorrect choice).

The modular system must be reflected in the following dimensions:

- Internationalization and mobility: the advantage was seen in two-way transfer of knowledge and experience;

- Interdisciplinarity: training of primary school teachers is characterized by multidisciplinarity which prior to modularization had been fragmented and atomized; a meaningful modularization created space for the integration of the study components;

- Combining teaching and research: emphasis on the application of new findings in the teaching process. 
The introduction of the European dimension in education was not a mere political or economic task. It is important to recognize the complexity of compromises and shared responsibility, especially in the case of teachers and professionals who train future teachers. The discovery of Europe was both a personal and professional concern for them, because they lacked direct experience and contacts with Western Europe (Walterová, 1997, 1998).

As far as undergraduate teacher training is concerned, it was necessary to establish the link between theory and practice. Some might argue that these are contrasting phenomena. However, J. Maňák (2011) states that the deepening of human knowledge leads to the overlapping of competences and close links between them. In the course of development, both theoretical knowledge and creative practice improved (although each area at its own pace).

The cooperation between educational theory and practice was not implemented on the same national level. Svatoš and Holý (2002) define the following concepts of teacher education (The issue of teacher training concepts is not unknown in foreign countries. A major representative was Kincheloe (1993) who formulated 4 basic types of concepts: behavioural concept, personality-based concept, skillbased concept, and concept based on the discovery and construction of educational knowledge. The Czech approach to education was inspired by this idea and its effort was to achieve the transition from positivist orientation to a constructivist approach.):

- Scientific concept: focus is on subject-specific scientific preparedness, while the psychodidactic, social and communicative components are limited;

- Activity concept: emphasis is on orientation in educational situations, management of practical activities, while the formation of the teacher's knowledge system is limited;

- Personality concept: development of communication and empathy, while attention on knowledge and concepts is limited.

According to the authors of the concepts the preparation of primary school teachers was dominated by the activity and personality approaches. Today's trends could be characterized as a combination of all three strategies.

Lukášová-Kantorková (2003) presents the following theoretical approaches to education. These include the following:

- Analytical model: focus is on analysing the teacher's qualities. In this context, the system of preparation is reduced to didactic skills;

- Analytical-synthetic model: direction from the analysis of the preconditions to the development of appropriate skills and activities. The system of preparation focuses on self-diagnosis;

- Reflective model: is based on educational theory and practice, which provides incentives for self-reflection. It enables the combination of the teacher's personality with relevant knowledge, skills, and activities. 
The latter model is considered the strategy that should become the basis of modern competitive education of future (primary school) teachers. It is because the model can flexibly respond to the process of professionalization of the discipline on the basis of improving the teacher's competences. Figure 01 below outlines the aspects related to this development.

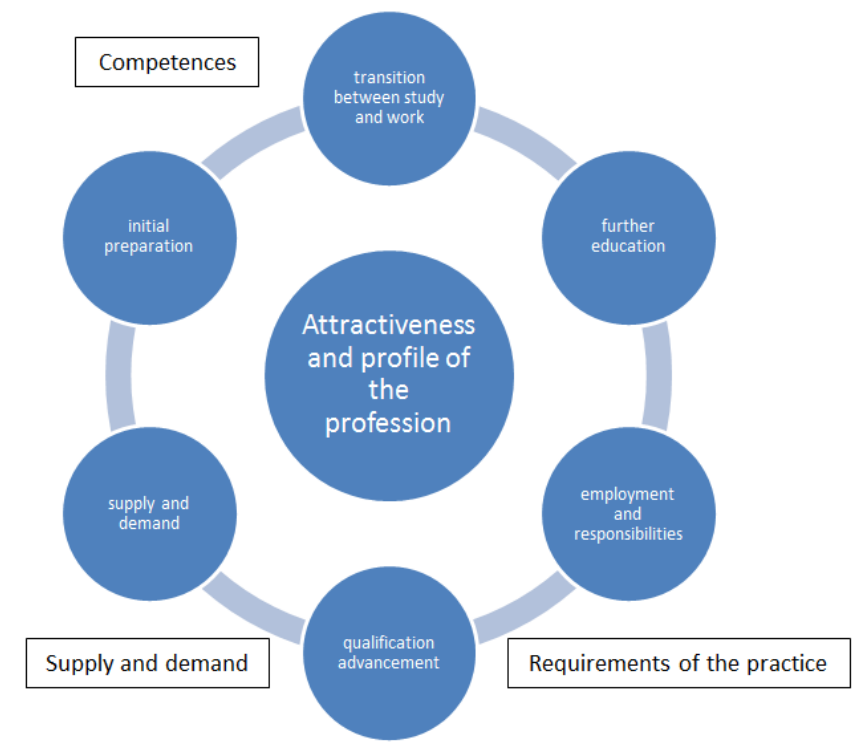

Figure 01. Aspects of the complexity of the profession-preparation and development Source: The Teaching Profession in Europe: Profile, Trends and Concerns, 2002

In the context of the professionalization of the teaching profession in primary school, which has been strongly supported since 1990s, one of the key aspects has been to define the teacher's key competences. Unfortunately, no professional teaching standard has been defined so far. As a result, a uniform system of classification that would define the key teacher's competences has not been established. This issue has been addressed by a number of Czech authors (including for example Helus, 2001; Lazarová, 2003; Nelešovská, 2008; Spilková, 2004; Švec, 2005; Vališová, 2004; Vašutová, 2004 and many others).

Each author considers the issue from a different perspective. However, all of them are important concepts for the determination of the current profile of the graduate of Teacher training for primary schools.

\section{What is the current concept of primary education?}

According to the profile, the graduates should be provided with the following competences: developmental-reflective, diagnostic, communicative, cooperative, self-reflective, subject-specific diagnostic, educational-research, educational-organizational, managerial, and projective-creative. The graduates should have multidisciplinary knowledge and skills in the areas related to linguistics, mathematics and natural science, national history, music, somatic issues, visual arts, and occupational issues. The graduates should have a broad cultural awareness (including literature, music, visual arts, and drama). The graduates have the skills and knowledge that contribute to health promotion and optimal prevention of undesirable effects of technology, understand and are able to teach their pupils in the area 
of social changes, resolve educational problems, and assess their educational activity. They have the capabilities necessary for creative, self-reflective, and self-regulatory development (Interní podklady Akreditační spis, 2018).

To achieve the highest possible level of graduate competences, the course of study must be of an intensifying nature and theoretical and didactic courses need to be continuously related to practice.

The structure of the study is set in line with the modern principles reflecting the transformation of higher education (Spilková \& Hejlová, 2010). These include the following:

- Integration of education: within educational disciplines, between education and psychology, between a course and its didactics, general didactics and course-specific didactics, theoretical study and practice;

- Personality development, cultural awareness and general level of education;

- Intensifying system of teaching practice throughout the whole period of study with an emphasis on the teaching activity and its reflection;

- Activity methods;

- Individualization of study and personal specialization.

In order to achieve the graduate profile, the study includes a logical content line. The underlying philosophy is the current concept of primary school, and the core of the study is in educational and psychological disciplines, course-specific didactics, and practice. The whole study is designed as a flexible system that allows the students' professional development and provides space for their specialization.

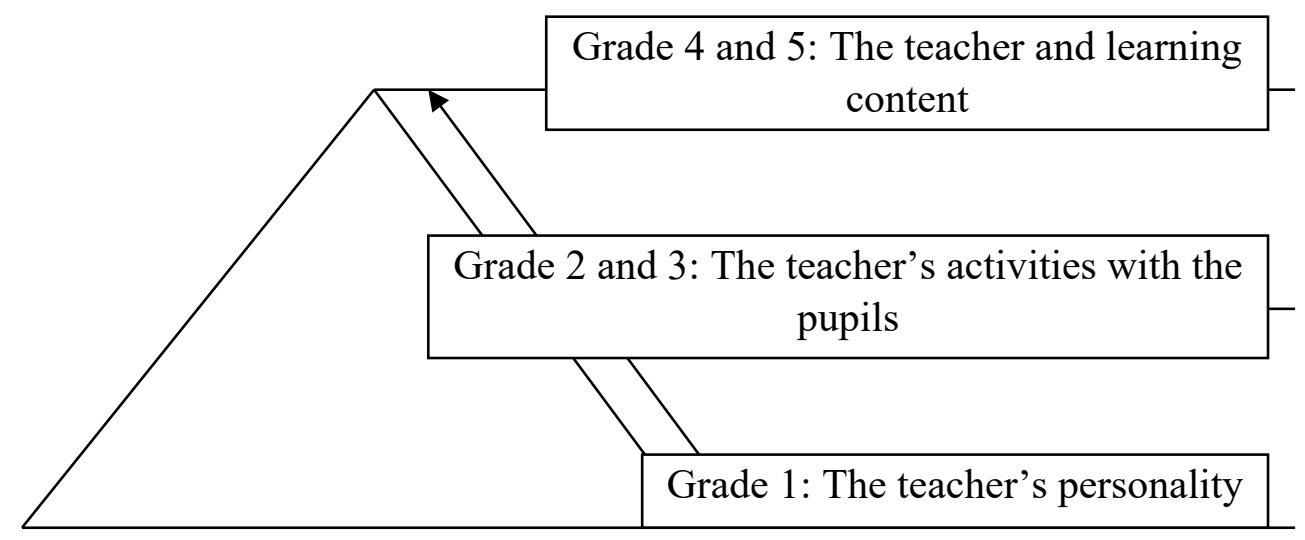

Figure 02. Content of the course for future primary school teachers Source: Interní podklady Akreditační spis, 2018

In the first year the students are encouraged to develop their own idea about their own teacher identity. In the second and third years, emphasis is on the deepening of self-awareness in the role of the teacher. In the fourth and fifth years, the core of undergraduate preparation is the reflection of the partial 
and final level of the adopted professional competences in a dynamic context (Figure 02). The final product of the system of undergraduate preparation is the individual teacher identity.

In the context of the reflective attitude to education (according to Lukášová-Kantorková, 2003), i.e. focusing on the link between theory and practice, teaching practices copy the content structure of the study. In the course of the five years, from the first week of study, teaching practices are offered in three categories:

- Classroom observation practice;

- Micro-teaching sessions;

- Own teaching practice

The current structure of undergraduate training of primary school teachers with an emphasis on teaching practice is in detail described in a paper by Provázková Stolinská (2020).

\section{Purpose of the Study}

The purpose of this paper is to present the important parts of a scientific study on the development of the concept of undergraduate training of future primary school teachers with an emphasis on teaching practice. The paper discusses what the current undergraduate students need. We believe that a very inspiring approach in the modernization of undergraduate teacher training is the Lesson Study method. In the Czech Republic, this method has so far not been used extensively. However, we believe that its application may improve the effectiveness of undergraduate preparation.

\section{Research Methods}

For the purpose of monitoring and evaluation of the effectiveness of undergraduate teacher training, a system has been in place for 20 years focusing on the assessment of students on teaching practices. This assessment focuses on their success rate (data measured by teacher trainers), but also on the challenges that they face (data from students on their teaching practice). In this way, feedback is acquired on the effectiveness of the structure of the study including suggestions for its improvement. The longitudinal research study is of the following structure:

- Analysis of accreditation documents (not carried out annually, but approximately once every three years);

- Assessment of students on teaching practice by teacher trainers (once per year);

- Questionnaire and interview with students on the challenges they face on their teaching practice.

The findings present the results of the research which was directly followed by the preparation of a new accreditation. The paper includes the responses of the teacher trainers and answers from the students' questionnaire. The total of 64 respondents equals the number of students on continuous teaching practice in one year. 


\section{Findings}

1. Assessment of students on teaching practice by teacher trainers (number of respondents 64 the results are shown in Figure 04 and Table 01)

The teacher trainers indicated their assessment of the students in the areas mentioned below on the following scale (Figure 03):

\section{$\underline{1}$}

23
4 5 6

1) Preparation for classes was rather indicative and general.

2) The professional level of preparation and presentation was rather low.

3) The selection of the methods did not correspond to the educational objectives and the real and specific conditions of the educational situation.

4) The teaching methods were rather usual and traditional, the procedures were ordinary.

5) Problems with establishing contact with the children.

6) Motivating children for work was not fully effective.

7) It appears that the student is not yet capable of an adequate reflection of his/her educational activity.

8) The educational aspects of the learning content were applied randomly and insufficiently.
Preparation for classes was well thought-out, elaborated, detailed (partial steps).

The professional level of preparation and presentation was very high.

The selection of the methods corresponded to the educational objectives and the real and specific conditions of the educational situation.

The teaching methods were mostly original and unconventional, the procedures were mostly creative.

The children were approached in an appropriate manner and close contact was established.

Motivating children was very effective.

The student is almost capable of a mature professional self-reflection.

The educational aspects of the learning content were applied in a deliberate and adequate manner.

Figure 03. The scale of the students assessment by the teacher trainers 


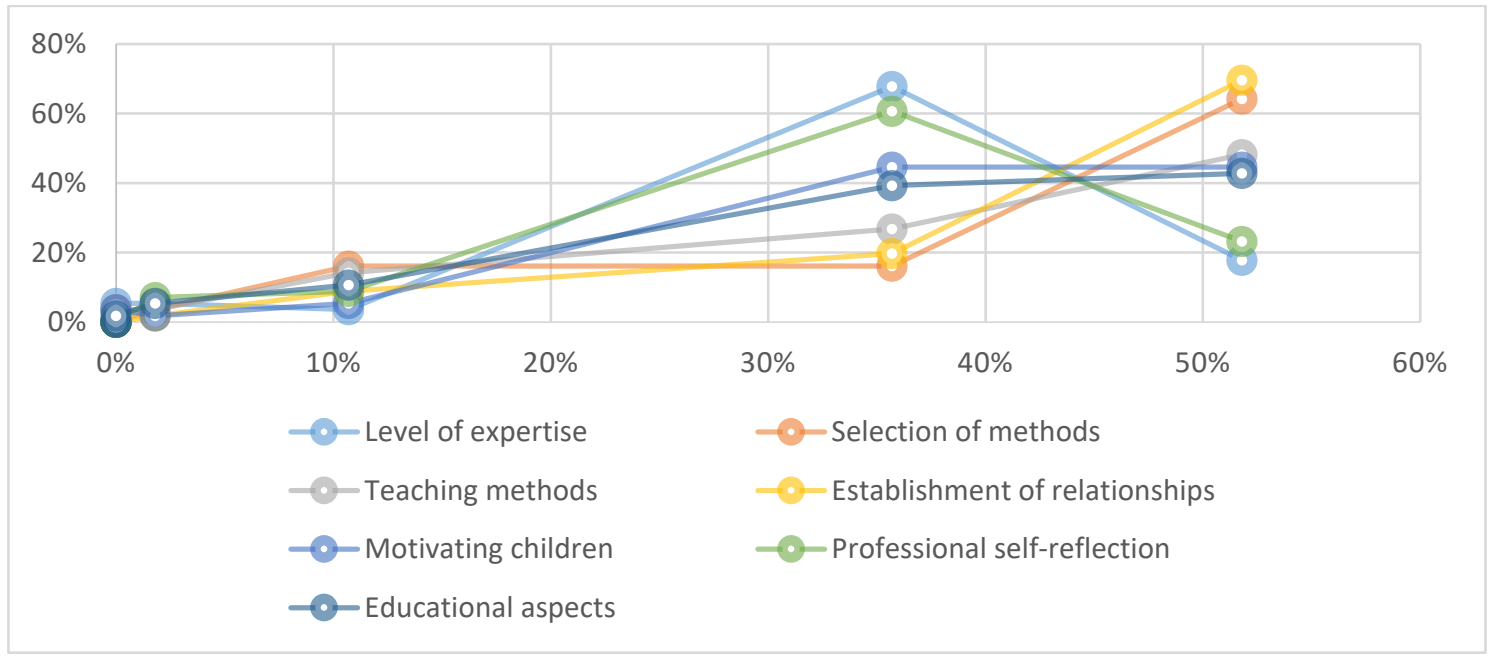

Figure 04. Assessment of the students on teaching practice

Table 01. Assessment of the students on teaching practice

\begin{tabular}{|l|l|l|l|l|l|l|l|l|}
\hline Assessment & $\begin{array}{l}\text { Preparation } \\
\text { for classes }\end{array}$ & $\begin{array}{l}\text { Level of } \\
\text { expertise }\end{array}$ & $\begin{array}{l}\text { Selection } \\
\text { of } \\
\text { methods }\end{array}$ & $\begin{array}{l}\text { Teaching } \\
\text { methods }\end{array}$ & $\begin{array}{l}\text { Establishment } \\
\text { of } \\
\text { relationships }\end{array}$ & $\begin{array}{l}\text { Motivating } \\
\text { children }\end{array}$ & $\begin{array}{l}\text { Professional } \\
\text { self- } \\
\text { reflection }\end{array}$ & $\begin{array}{l}\text { Educational } \\
\text { aspects }\end{array}$ \\
\hline 1 & $0 \%$ & $0 \%$ & $0 \%$ & $0 \%$ & $0 \%$ & $0 \%$ & $0 \%$ & $0 \%$ \\
\hline 2 & $0 \%$ & $0 \%$ & $0 \%$ & $4 \%$ & $0 \%$ & $0 \%$ & $0 \%$ & $0 \%$ \\
\hline 3 & $0 \%$ & $5 \%$ & $0 \%$ & $4 \%$ & $0 \%$ & $4 \%$ & $0 \%$ & $2 \%$ \\
\hline 4 & $2 \%$ & $5 \%$ & $4 \%$ & $4 \%$ & $2 \%$ & $2 \%$ & $7 \%$ & $5 \%$ \\
\hline 5 & $11 \%$ & $4 \%$ & $16 \%$ & $14 \%$ & $9 \%$ & $5 \%$ & $9 \%$ & $11 \%$ \\
\hline 6 & $36 \%$ & $68 \%$ & $16 \%$ & $27 \%$ & $20 \%$ & $45 \%$ & $61 \%$ & $39 \%$ \\
\hline 7 & $52 \%$ & $18 \%$ & $64 \%$ & $48 \%$ & $70 \%$ & $45 \%$ & $23 \%$ & $43 \%$ \\
\hline
\end{tabular}

Interpretation of the results: Looking at the results of the research, a positive aspect is that none of the teachers indicated the lowest value in the assessment of the students on teaching practice. Generally, the assessment in all categories was in the upper zone. The highest values related to the students' abilities to establish positive relationships with their pupils, they were also able to select appropriate teaching methods and reflect on their own activity, and they showed a high level of expertise.

From a longitudinal perspective, there were no significant deviations in the results. This suggested that their study had a positive effect on their teaching practice. However, the students' responses were quite different.

\section{Questionnaire and interview with the students concerning the challenges they face on their} teaching practice (number of respondents 64 - the results are shown in Figure 5 and Table 2)

The students completed the questionnaire and a group interview was held in which they commented on the difficulties they had faced on their teaching practice. 


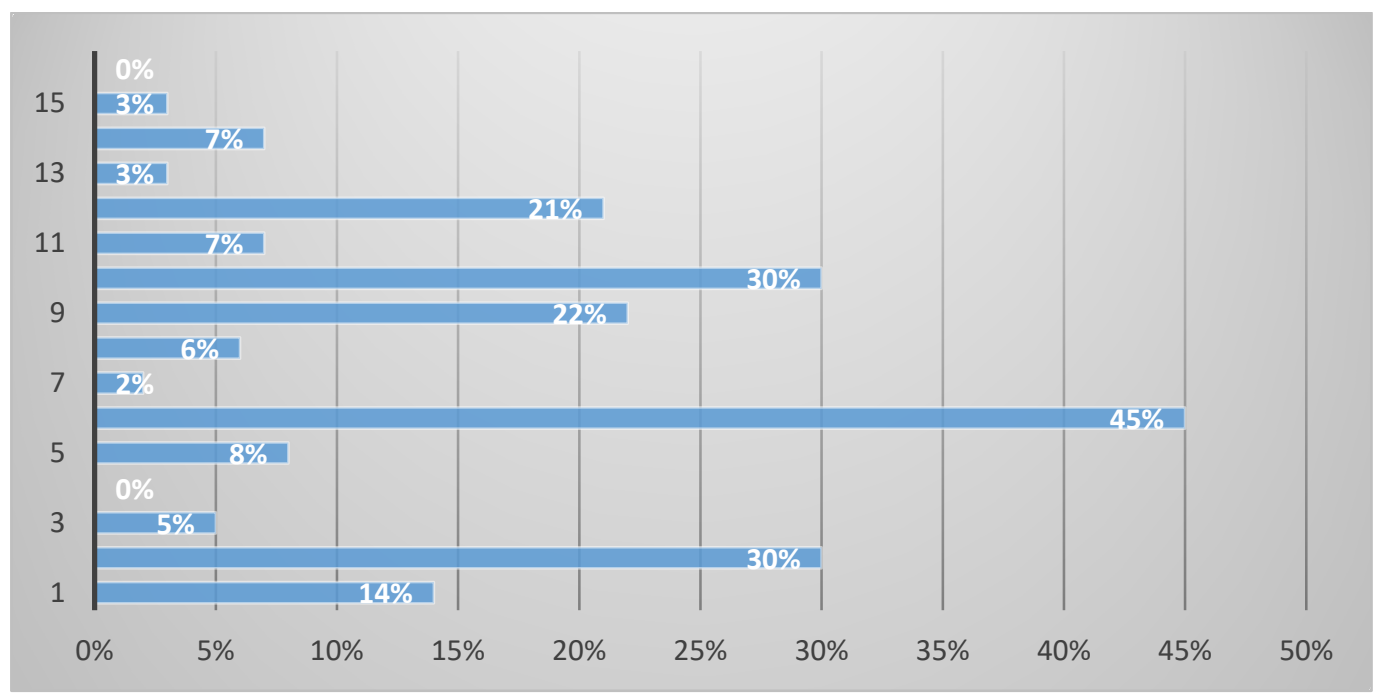

Figure 05. Students' difficulties on teaching practice

Table 02. Legend for Graph 2

\begin{tabular}{|l|l|}
\hline $\mathbf{1}$ & I had problems formulating the goal of the lesson \\
\hline $\mathbf{2}$ & Preparation of the lesson was very time-consuming for me \\
\hline $\mathbf{3}$ & The selection of methods and their implementation was difficult \\
\hline $\mathbf{4}$ & I was unable to use the teaching aids in a functional way \\
\hline $\mathbf{5}$ & I had difficulty leading the lesson according to the planned methodological procedures \\
\hline $\mathbf{6}$ & At times I was unable to activate all pupils \\
\hline $\mathbf{7}$ & I focused especially on the active pupils \\
\hline $\mathbf{8}$ & I found it difficult to explain unfamiliar terms so that the pupils could understand \\
\hline $\mathbf{9}$ & I had some problems with formulating questions \\
\hline $\mathbf{1 0}$ & I was often unable to maintain reasonable discipline \\
\hline $\mathbf{1 1}$ & $\begin{array}{l}\text { For the reasons mentioned above, I was sometimes unable to use appropriate educational } \\
\text { measures in classes }\end{array}$ \\
\hline $\mathbf{1 2}$ & I had problems with standard pronunciation \\
\hline $\mathbf{1 3}$ & $\begin{array}{l}\text { I failed to adopt the technique of verbal expression properly (articulation, intonation, volume, } \\
\text { etc.) }\end{array}$ \\
\hline $\mathbf{1 4}$ & I had problems using non-verbal communication (gestures, facial expressions, etc.) \\
\hline $\mathbf{1 5}$ & I had great problems with writing on the blackboard \\
\hline $\mathbf{1 6}$ & I was often unable to control stage fright \\
\hline
\end{tabular}

Interpretation of the results: The results showed that only $29.81 \%$ of the students did not experience any difficulties on their teaching practice.

According to the teacher trainers, the students did not have any problems with establishing a positive relationship with the pupils, which is considered the basic criterion for effective teaching. Despite this fact, $45 \%$ of the students had difficulties with activation and communication with the pupils directly in classes.

While the teachers assessed the students positively in the area of expertise and preparation for classes, the students indicated reserves in this area. Some of them even reported that they had spent 2 hours preparing for 1 lesson (45 minutes). 
Other difficulties included didactic problems (sequencing of the learning content), respecting and implementation of an individual approach in teaching the whole class, and addressing educational problems.

\section{Conclusion}

The results of the research survey describe the students' performance in the educational process. However, the students themselves feel alone in the preparation for teaching practice and address a number of other serious professional difficulties. The results of the longitudinal research are regularly evaluated on a yearly basis. The results are then used to modernize and update the study courses. The assessment of the specific year was crucial in the preparation of the new accreditation file according to which study has been governed since 2019/2020. This file defines a new structure of teaching practices in order to ensure a higher degree of connection between theory and practice, thereby supporting the students in their initial teaching efforts.

The development of the new structure of teaching practices was associated with the modernization of the content. An interesting and inspiring concept for modern undergraduate preparation of future teachers in the Czech Republic is the foreign Lesson Study method.

This is an action research that addresses an educational problem in the real practical environment and is built on a plan of changes, collection of information, reflection, and practical activity. In addition, this method includes elements of the participant, cyclic, qualitative, and reflective approaches to action research (Hendl, 2016).

This method helps develop the teacher's educational knowledge-relating especially to the content, curriculum, and the learning process (Hart et al., 2011). However, the method does not only focus on the skills of a single teacher but monitors the effectiveness of the strategies in the achievement of the set objectives of education. The responsibility for the whole lesson project is on the entire team involved in its development (Šrámková, 2017).

A significant element in the success of Lesson Study is classroom observation. In this context, an important fact is that the team of teachers who collaborate on the preparation of the lesson focus on the predefined aspects during classroom observation. As a result, the teacher who actually teaches the lesson is in a safer environment compared with traditional observations where the preparation and delivery is the responsibility of the teacher (Vondrová et al., 2016). Another essential element is reflection. We are committed to a qualified educational reflection including the objectives and content of education, methods of work, and pupils' comprehension. There are two types of reflection: individual reflection (by each member of the team) and group reflection, in which individual reflections are discussed.

Lesson Study should develop the teachers' reflective skills ranging from description to assessment and interpretation.

A detailed description of the Lesson Study method is presented in a paper by Provázková Stolinská (2020). 
https://doi.org/10.15405/epiceepsy.20111.8

Corresponding Author: Dominika Provázková Stolinská

Selection and peer-review under responsibility of the Organizing Committee of the conference

2672-8141

\section{Challenges and risks of the method in the Czech Republic}

In the Czech Republic the method has so far not been used extensively. However, some of the strategies concerning the application of the method can be adopted from abroad.

\section{Non-European origin}

The method originated in Japan. Vondrová et al. (2016) refer to a Japanese source, according to which the method is not mandatory or funded, but teachers conduct on average 10 experimental lessons per year, because they perceive it as a natural part of their work. In addition, teachers can also visit classrooms in other schools. In Japan, teaching is considered a public activity open to other teachers. In other countries where the method has developed (mostly in the USA, UK, South America, Southeast Asia, and Australia), education is mostly private. This may also be a potential risk in the Czech Republic because primary school teachers may feel concerns about making their classes available to others.

\section{Emphasis on respecting the stages of the method}

Another difference between Japan and other regions is the focus of the stages of Lesson Study. In Japan, emphasis is on the objective and selection of appropriate tasks. In other countries, focus is rather on the teaching process and reflection. Perhaps because these are the most 'visible' stages.

\section{Demanding nature of the initial efforts}

During the efforts to implement Lesson Study in the Czech Republic, there was a degree of reluctance to carry out the follow-up experimental lesson with the same team because of the demanding nature of this activity. When the teachers overcame their reluctance and attempted further implementation, they started to think about a new suitable theme for implementation. According to Sládková (2017), teachers had probably adopted (or at least understood) the steps in each stage.

Despite the risks we believe that the application of the Lesson Study method in the Czech Republic has a great potential. Since 2017, we have been actively involved in analysing the method and thinking about possible ways of its implementation in undergraduate preparation in Teacher training for primary schools. So far, we have focused on experience gained by our foreign partner universities and on formal application possibilities in the Czech Republic. Now the period of implementation comes.

\section{Acknowledgments}

The paper is a partial outcome of the project No. VaV_PdF_2020_003 Development of the concept of undergraduate training of primary school teachers with an emphasis on communication competences.

\section{References}

70 let Pedagogické fakulty Univerzity Palackého v Olomouci [70th Anniversary of the Faculty of Education, Palacký University Olomouc] (2016). Olomouc, UP.

Hart, L. C., Alston, A. S., \& Murata, A. (Eds.) (2011). Lesson study research and practice in mathematics education. Springer.

Helus, Z. (2001). Alternativní pohled na kompetence učitelů. In Učitelé jako profesní skupina, jejich vzdéláváni a podpưrný systém [An alternative view of teachers' competencies. In Teachers as a professional group, their education and support system]. UK. 
Hendl, J. (2016). Kvalitativni výzkum: Základní teorie, metody a aplikace [Qualitative research: Basic theories, methods and applications]. Portál.

Interní podklady. Akreditační spis [Internal documents. Accreditation file] (2018).

Kasíková, H. (1994). Pedagogické otázky současnosti [Pedagogical questions of the present]. ISV nakladatelství.

Kincheloe, J. L. (1993). Toward a Critical Politics of Teacher Thinking. Mapping the postmodern. Bergin and Garvey.

Koncepce pregraduální př́pravy učitelů základních a středních škol [Concept of undergraduate preparation of elementary and secondary school teachers] (2004). Praha. $<$ https:/www.msmt.cz/uploads/odbor_30/Jakub/Koncepce_pregradualni_pripravy_ucitelu_zaklad nich_a_strednich_skol.pdf>

Lazarová, B. (2003). Krizově-intervenční kompetence učitelů [Crisis-intervention competencies of teachers]. Pedagogická orientace [Pedagogical orientation], 4.

Lukášová-Kantorková, H. (2003). Učitelská profese v primárním vzdélávání a pedagogická př́prava učitelů /teorie, výzkum, praxe [Teaching profession in primary education and pedagogical training of teachers / theory, research, practice]. PdF.

Maňák, J. (2011). K problému teorie a praxe v pedagogice [On the problem of theory and practice in pedagogy]. Pedagogická orientace [Pedagogical orientation], 21(3).

MŠMT (2013). Rámcový vzdělávací program pro základní vzdělávání [Framework educational program for basic education]. <http://www.nuv.cz/file/433 1 1/>

Nelešovská, A. (2008). Pohled studentů (učitelů) na pedagogické kompetence [The view of students (teachers) on pedagogical competencies]. In Současnost a budoucnost učitelského vzdělávání [In Present and future of teacher education]. REPRONIS.

Provázková Stolinská, D. (2020). Trends in practical undergraduate training of future primary school teachers. Independence and Interdependence. London, UK.

Sládková, K. (2017). Lesson study napríč republikou. Kritická gramotnost o praxi, textech a kontextech [Lesson study across the republic. Critical literacy about practice, texts and contexts]. Praha.

Spilková, V. (2004). Současné proměny vzdělávání učitelů [Current changes in teacher education]. Paido.

Spilková, V., \& Hejlová, H. (Eds.) (2010). Příprava učitelů pro primární a preprimární vzdělávání v Česku a na Slovensku: Vývoj po roce 1989 a perspektivy [Teacher training for primary and preprimary education in the Czech Republic and Slovakia: Developments after 1989 and perspectives]. UK.

Šrámková, K. (2017). Čtenářské kontinuum a lesson study. Kritická gramotnost o praxi, textech a kontextech [Reading continuum and lesson study. Critical literacy about practice, texts and contexts]. Praha.

Svatoš, T., \& Holý, I. (2002). Konvergentní př́istup k utváření dovedností studentů [Convergent approach to shaping skills]. In V. Švec (Ed.), Cesty $k$ učitelské profesi: utváření a rozvíjení pedagogických dovednosti [Ways to the teaching profession: formation and development of pedagogical skills]. Paido.

Švec, V. (2005). Pedagogické znalosti učitele: teorie a praxe [Teacher pedagogical knowledge: theory and practice]. ASPI.

The Teaching Profession in Europe: Profile, Trends and Concerns. (2002) EURYDICE.

Vališová, A. (2004). Respektování autority - problém rodiny, školy i společnosti [Respecting authority the problem of family, school and society]. In Rozvoj české společnosti v evropské unii [Development of Czech society in the European Union]. MATFYZPRESS.

Vašutová, J. (2004). Profese učitele v českém vzdělávacím kontextu [The profession of teacher in the Czech educational context]. Paido.

Vondrová, N., Cachová, J., Coufalová, J., \& Krátká, M. (2016). „Lesson study“ v českých podmínkách: Jak učitelé vnímali svou účast a jaký vliv měla na jejich všímání si didakticko-matematických jevů ["Lesson study" in Czech conditions: How teachers perceived their participation and what influence it had on their perception of didactic-mathematical phenomena]. Pedagogika, 66(4).

Walterová, E. (1998). Strategie realizace Evropské dimenze ve vzdělávání učitelů [Strategies for implementing the European dimension in teacher education]. In Připravujeme učitele pro 21. stoleti a vstup do Evropy [We are preparing teachers for the 21 st century and entering Europe]. UP.

Walterová, E. (1997). Objevujeme Evropu [We are discovering Europe]. UK. 